\title{
INTER-RELIGIOUS CONFLICTS: A REVIEW OF ZIMBABWE'S RELIGIOUS LANDSCAPE, POST-INDEPENDENCE
}

\author{
Obediah Dodo \\ Bindura University of Science Education \\ P. B. 1020 Bindura, \\ Zimbabwe \\ +263 772910482, obediahdodo@gmail.com \\ URL: http://ijourels.org.ng $\quad \underline{\text { https://dx.doi.org/10.4314/ijrs.v7i2.4 }}$
}

\begin{abstract}
The study sought to explore inter-religious conflicts in post-independent Zimbabwe and respective resolution measures. This followed a clear dominance of the religious terrain by one religion and the observance of one religious' rites in public forums in a secular state. The qualitative study following a historical exploratory design was influenced by Social Dominance Theory. 32 religious participants were sampled purposively from the four main religious fronts; African Traditional Religion (ATR), Pentecostal Christianity, Islam and Hinduism. Data were collected using structured interviews, and analysis of archival material. The paper argues that the peace and co-existence of the different religions is a result of institutional 'diplomatic quite policy' through settlement planning, education curricula, ridicule and demonization, suppression of activities and deprivation of public space. It found that Christianity suppresses other religions as a way of preventing potential religious conflicts.
\end{abstract}

Keywords: Conflict resolution, Religion, Conflict prevention, Circumstantial coercion.

\section{Introduction}

Zimbabwe, like several African countries post-independence, is defined by the existence of varying religions both in urban and rural areas. Just like in several other countries where inter-religious conflicts have been recorded, Zimbabwe has not been spared despite the existence of a variety of preventive systems and strategies at various societal levels. Zimbabwe constitutionally is a secular state as defined that; it is a republic [Section 1 of the Constitution Amendment No. 20] and supposedly a constitutional democracy [Section 3(a)]. The State is based on: i) the recognition of the natural human dignity and worth of each and every human being [Sections 3(f), 48 and 51]; ii) fundamental human rights and freedoms [Section 3(c) and 49]; and iii) the recognition of the equality of all human beings [Sections 3(f) and 56]. While this means allowing all religions equal space and recognition, it is Christianity that has dominated and in the process, ensured continued suffocation of the rest. This has ultimately seen non-Christians having to go underground and in the process having to conceal their grievances and conflicts with all the other stakeholders. This study seeks therefore, to establish inter-religious relationships with particular focus on 
Pentecostalism, their enjoyment of the operational space and possibly identify some of the conflicts and how they have been resolved at various societal levels.

\section{Background}

Zimbabwe is multinational with a variety of religions. Constitutionally, Zimbabwe is a secular state allowing various religious freedoms and practices. According to the Zimbabwe Demographic Survey, ${ }^{2}$ Chitando $^{3}$ and Dodo et $\mathrm{al}^{4}$ the following membership estimates were recorded: Christianity has $78 \%$ $(10,000,000)$ [with Pentecostalism claiming over 30\%], African Traditional Religion (ATR) with 18\% (2 500,000), Islam with 3\% (85 000) and Hinduism (7800) and others taking less than 1\%. However, because Zimbabwe's birth registration and routine census do not record religious orientations, it has been difficulty to record religious statistics accurately. This difficulty has also been compounded by the fact that generally Zimbabweans are syncretic as they mix beliefs in pursuit of salvation and solutions to varying social and economic challenges. Accurate statistics have also been affected by the fact that some religions are looked down upon so much so that some communities do not want to be either associated with them or seen near or around them. This stigmatisation has been popularized by Pentecostalism which labels other religionists as satanic and inhumane. What has often been noted is that the majority of over $60 \%$ turn to traditionalists for assistance and intelligence. This is done through marriage, appeasement of the dead, inheritance rituals and acknowledgement of other significant traditional wakes and days like Friday as a non-working day and November as a sacred month for resting; a strong sign of belief in ATR. ${ }^{5}$ Adherents of ATR believe that some long dead people, commonly called ancestors/ancestresses are channels to God and that they lead and take care of the living.

ATR is indigenous to native Africans, while Christianity as a religion has its sources in Jesus called the Christ who was a Jew. Jesus was crucified for allegedly claiming to be God. Believers in this religion are called Christians. Islam traces its own roots to the biblical Ishmael, son of Abraham and as a religion, was founded by a prophet called Muhammad, a Meccan. On the other hand, Hinduism developed through years of various religious inter-mingling in India. The religion believes in God called Brahma. ${ }^{6}$

The demographic structure of the religions in Zimbabwe has also been shaped along political, ethnic and racial lines. This was perpetuated by some of the laws and policies dating from as far back as the colonial era. Some of the laws included the Municipal Act of 1897 which described the settlement conditions for Africans, the Reserve Act of 1903 and Boards like the 1903 Rhodesia Native Labour Bureau which helped the Chamber of Mines to force Africans to work in the available mines. There was also the Land Apportionment Act of 1930 which entrenched the racial partitioning of land in Zimbabwe (Dodo, forthcoming). Such segregatory laws have up to this day seen communities sharing a common belief especially immigrant workers from Malawi and 
Mozambique who are Muslims clustering themselves in either mining or farming settlements. There are clearly defined settlements that house distinct members of particular religions.

Before the coming of the Europeans, communities in the present Zimbabwe who were long involved in international trade with other states from as far as the Far East and China from as early as 1290 till the 1600 had their strong religious beliefs and inclinations. It must be noted that the first Islamic Arabs came to Zimbabwe in $900 \mathrm{AD}$. These traders' propensity to convert locals into their religion was limited as they focused more on trade. However, it was around December 1560 when a missionary called Gonzalo da Silveira moved into one of the states and converted some members of the Mutapa royal family into Christianity. All attempts by the Islamic preachers to convert failed as Christian preachers had already monopolised with their ideology. The coming of the early Christian missionaries changed the locals' approaches to conflict and conflict resolution given that the missionaries preached peace, harmony and tolerance. $^{7}$ This, to some extent explains the institutional 'diplomatic quite policy' by a largely Christian community in Zimbabwe to the other religions.

\section{Methodology}

The study was conducted qualitatively following a historical exploratory design. Data was collected using structured interviews following a given set of questions, analysis of archival material, documents, and literature review within a defined sphere of study and stretch of time. All the interviews were preceded by thorough studies of relevant material. The study followed an anti-positivist approach which believes in depth of data rather than width. Therefore, a total of 32 religious participants were equally sampled purposively from across the four main religious fronts; ATR, Pentecostalism, Islam and Hinduism. Eight from each religion were expected to adequately cover all the aspects in the research questions. Content Analysis approach was applied to analyse data which was in audio form. The analysis of written data was continual and informed by the Framework Approach to qualitative analysis. It involved the transcription of all the data, record appraisal, and identification of vital emergent themes, development of a thematic framework, contrast of views from various groups of participants and the development of explanations. Varied viewpoints informed the analysis. The approach also allowed analysis of mannerisms, attitudes and feelings by the participants as a way of authenticating data and credibility of the participants. Prior to the study, all the participants were informed of the essence and expectations of the study, especially on the need for confidentiality, anonymity and freedom to withdraw from participation since issues discussed about religion can be sensitive and emotional.

\section{Theoretical Framework}

The study was influenced by the Social Dominance Theory by Sidanius and Pratto which argues that in society, prominent communities would as much 
as possible want to dominate and overshadow other available communities especially if they are in competition for scarce resources. ${ }^{8}$ The theory contends that intergroup domination, discrimination, and bigotry are the strategies through which societies establish group-based structures, in which members of governing groups enjoy a lop-sided portion of the good. ${ }^{9}$ True to the theory in Zimbabwe, Pentecostalism has adopted a stance meant to keep other religions inactive both as a way of preventing potentially explosive conflicts and monopolization of the available membership pool.

\section{Religious Conflicts and Previously Applied Conflict resolution Approaches}

Religious conflicts are common world-over. History shows that some universal religions have on several occasions employed violence to protect their values and teachings while in some instances, religions get entangled in politics such that they end up either fueling or partaking in the conflicts. Some of the religious teachings and practices perpetuate violence and conflicts.

ATR and Hinduism express solid support for democracy and religious freedom. However, Pentecostalism and Islam want democracy expressed along their own understandings. This, according to Lewis and PFRPL explains why Pentecostals would like to base civil law on the Bible while Muslims prefer it based on the Koran. It is all political; the desire to control decisions, knowledge, development and cultures amongst others. ${ }^{10}$

Some scholars, such as Sampson and PFRPL concur that there is serious distrust and hostility between different religions largely because of their ignorance about each other's religious practices and doctrines and competition for membership. Unfortunately, they seek no knowledge for fear of association and pride. This to some extent explains why Muslims claim to give a portion of their wealth to charity (zakat) and accuse Pentecostalists of robbing the poor. ${ }^{11}$

Though there are visible differences in ideology amongst religions, there are some areas of commonalities. Hindus, ATR adherents, Pentecostalists, and Muslims, all express serious disapproval of prostitution, suicide, and abortion, while ATR has a moderate view towards homosexuality. They all seek peace and order albeit through different means and strategies. However, Christians and Muslims are not as peaceful as adherents of ATR, because the latter does not proselytize. PFRPL also posit that inter-religious conflicts in Zimbabwe are not as grave as other pressing challenges like crime, unemployment and corruption. ${ }^{12}$

Closer to the case under review, religions have a well-documented history of partaking in various struggles against oppression. The earliest of the documented cases date back to the 1960-1970s' liberation war when basically all the major religions offered some help to the liberation movements. ${ }^{13}$ Minority religions such as ATR, Islam and Hindu have not claimed limelight with their assistance due to ridicule, stereotyping, prejudice and demonization. ${ }^{14}$ Some of the conflicts that also involved religious movements include the Anglican Church and some apostolic groups. The Anglican Church experienced a protracted intramovement conflict from 2007 till 2013 following a realisation by the church that 
the then leader, Bishop Nolbert Kunonga, was stirring violence through sermons supporting a particular political party. ${ }^{15}$ The church experienced serious violence and persecution leading to the excommunication of Nolbert Kunonga in 2013. Bishop Johannes Ndanga of the Union for Development of Apostolic Churches in Zimbabwe (UDACIZA) has often embroiled himself in various conflicts and cases of violence especially ahead and during national plebiscites in Zimbabwe. Ndanga and UDACIZA often engage in conflicts with other apostolic sects especially when canvassing for political support for the ruling regime.

With regards to some of the recorded conflicts in Zimbabwe, there have been some religious groups that played various prevention and resolution roles. A clear case in point involves CCJP through its researches and advocacy work on the Gukurahundi genocide which was experienced in Matebeleland and Midlands provinces between 1982 and $1987 .{ }^{16}$

Both Christianity (with little support from Pentecostalism) and Islam have often intervened in various peace-building programmes by supporting development initiatives and poverty reducing projects. It is on record that several schools, clinics, hospitals and training institutions have been sponsored by some of these religions. There are also instances when the same religions have distributed food, clothing and medical supplies to various communities as poverty mitigating measures. ${ }^{17}$ Closely related, the same religions have also raised varied concerns whenever Zimbabwe finds itself mired in conflicts and violence.

\section{Findings:}

\section{How religious movements enjoy operational space}

In response to the question about domination of the religious space by some religions, all the 32 participants indicated that there are few Zimbabweans who have not come across Christianity in some form and at some stage especially given that in most schools, pupils are forced to learn it. Twenty four of the participants (excluding Pentecostals) indicated that some Pentecostals associate themselves with traditional practices to address specific challenges. Six participants from ATR argued that of the 3,000,000 estimated Pentecostals, about 2,000 000 of them also strongly believe in ATR and are sometimes following the former for the following reason: for solution during times of sorrow and hardships. The participants also pointed out that large membership that was claimed by Pentecostals was to some extent being used to suppress other religions' activities on the ground. It was also revealed that the imbalance in religious membership had also helped to weaken other religions from demanding operational space.

However, it was revealed that historically, religions have created their own 'kingdoms' where they enjoy worshipping and conducting their activities without interference and competition. Some of the areas that are clearly defined settlements housing members of particular religions are as shown in fig. 1. 
Fig. 1 Settlements along Religions

\begin{tabular}{|l|l|}
\hline \multicolumn{1}{|c|}{ AREA } & RELIGION \\
\hline Belvedere- Harare & Hindu \\
\hline Ridgeview- Harare & Islam \\
\hline Dzivarasekwa- Harare & Islam \\
\hline Generally all-over & Christianity \\
\hline Monavale- Harare & Budhism \\
\hline Rhodene- Masvingo & Hinduism \\
\hline Rio Tinto- Kwekwe & Islam \\
\hline Athlone- Gweru & Islam \\
\hline Generally all over & ATR \\
\hline
\end{tabular}

Participants from the Islamic religion (4 Sheiks and others) indicated that although statistically, Islam is viewed as a minority religion, it has managed to draw a large following especially from Pentecostalism capitalizing on its development-oriented approach. The participants revealed that Islam does not emphasise on 'disempowering' communities by demanding tithe and other levies. Rather, it was revealed that poor and vulnerable communities are prioritised for development and empowerment drawing resources from willing donors.

From the participants and the reviewed literature, it was glaringly evident that there are more Christian institutions in most areas than any other religion. This is attributable to the legacy of colonialism as explained by Dodo where Christianity was vigorous and determined in its mission to convert the locals unlike Islam which adopted a more peaceful and trade-interaction approach. ${ }^{18}$ It was also noted that the estimates extracted from some documents and literature may not be near any accurate statistics given the non-existence of any credible and scientific method of determining religions' membership statistics. The figures were mainly derived from church membership records which may be inaccurate due to dual membership amongst other reasons.

\section{Inter-Religious Relationships}

All the 32 participants pointed out that with regards to inter-religious relationships, there was an unfair and grossly 'suspicious' but 'silent' relationship through national pressure groups. Some of the pressure groups include; Zimbabwe Council of Churches (ZCC), Evangelical Fellowship of Zimbabwe (EFZ), and Zimbabwe Christian Alliance (ZCA) on one side and Majlisul Ulama Zimbabwe (MUZ), Zimbabwe Moslem Youth Organisation (ZMYO), Zimbabwe Islamic Mission (ZIM) and African Muslim Agency (AMA) and Zimbabwe National Traditional Healers' Association (ZINATHA) and Zimbabwe Traditional Healers' Association (ZITHA) amongst others on the other. 
Thirty participants ( 8 Muslims, 8 Hindus, 8 Pentecostals and 6 ATR) expressed discomfort about interreligious marriages, saying they would not be happy if their child were to marry someone from the opposite faith. Muslims, Hindus and Pentecostals expressed complete dislike of such marriages whereas, two ATR indicated that they were not worried for as long as there was genuine love. However, it was observed that Muslims were more liberal than Pentecostals having their child marrying from another religion. While all Pentecostal and ATR participants concurred that there was peace and a high degree of tolerance, the other 14 participants (8 Muslims and 6 Hindus) revealed that the relationship was tilted towards Pentecostals who dominated in most political, social and economic spaces.

Twenty-two participants (excluding Pentecostals and 2 ATRs) gave out that despite the constitution clearly allowing all religions equal recognition and spaces, it was only Pentecostalism that is recognised especially at public forums. Two participants ( 2 Muslims) cited the recital of Christian prayers at all gatherings at the National Heroes Acre and during all state university graduation ceremonies. This, according to the participants, infringes on the rights of other citizens, with regard to religious freedom. One Muslim expressed dismay at how Pentecostals perceive the former, saying "When they hear about Muslims involved in conflicts in the East, they tend to generalize and paint every other Muslim with the same brush, whereas Jihad is not always without a genuine cause, and that they fail to realize that there are also more Pentecostals involved in conflicts elsewhere including here in Zimbabwe, claiming that Islam is a religion of peace. On the other hand, one Christian remarked, "We cannot allow such forms of religions as Islam to penetrate our backyards, this is a Christian state".

Twenty three participants (5 Muslims, 5 ATR, 8 Pentecostals and 5 Hindus) voiced concern over religious extremism reported in the media in various countries. However, no particular religion took responsibility for the extremism arguing that it was a case of failing to appreciate or respect practices and laws in other religions. On this note, 26 participants (8 Muslims, 7 ATR, 8 Pentecostals and 3 Hindus) attributed their liking for the use of their doctrines and laws to craft civil laws with Pentecostals and Muslims preferring Bible and Koran respectively. While Muslims believe that their own laws (Sharia) lessen law-breaking, penalties like stoning people who commit adultery and flagellation or cutting off hands for crimes such as theft and robbery, could not be accepted lightly by the other religions. Eight Muslim participants felt that Muslim numbers in Zimbabwe were too low to push for the adoption of such laws.

\section{Identified Conflicts and Applied Prevention and Resolution Measures}

All the 32 participants acknowledged the existence of various conflicts on the ground as posited by Devine. ${ }^{19}$ Recognizing that generally Zimbabwe is regarded as a Christian state though constitutionally it is secular; thus granting equal religious rights, according to 18 participants, (7 Muslims, 4 Pentecostals, 3 
ATR and 4 Hindus) there has been over time an orchestration by the government of what this study may refer to as 'diplomatic quite policy', which has entrenched Christianity in almost all social, political and economic spheres to the detriment of other religions. One participant from the Hindu community remarked; "We have selected to stand aloof because of the attitude displayed by both government and our Pentecostal counterparts who seem to be intolerant of other (minority - emphasis mine) religions. These guys do not realize that the massive poverty within their members could be a reflection of the fallacy in their beliefs and weaknesses in their God". While some of these systems have disadvantaged minority religions in as far as free practice is concerned, to the authorities, they help prevent the manifestation of potential conflicts and also to resolve the few that might have developed. It was evident in participants from Islam and Hinduism that they showed serious concern and disapproval of what is prevailing on the ground at the instigation of government, prevailing structures, and systems.

Five Pentecostal participants revealed that the type of human settlement in Zimbabwe is deliberately designed to ensure that there is limited concentration of communities of the same religion in the same area. According to the participants, having Pentecostals all over is meant to neutralize other religions ensuring that they do not engage in conflicts and violence. All the 22 but two participants from the ATR, Hindu and Islam, however, reported that there was a lot of ridicule and demonisation within the religious playing field largely perpetuated by Pentecostals, driving Pentecostalism aggressively. Three participants cited a conflict in 1996 when Pentecostals, led by Evangelical Fellowship of Zimbabwe (EFZ), embarked on a campaign meant to force the Zimbabwe Government to stop engaging Muslims in slaughtering beef that was to be eaten by the Christian majority. The campaign also mobilised Christians against buying halal licensed merchandises in shops. On the same subject, two participants from Pentecostalism indicated that EFZ had argued that religious interests of a minority had been permitted to undermine the rights of the religious majority in a case involving a popular food item.

Twenty three participants coming from among Muslims (8), Hindus (8) and ATR (7) complained that they were being denied free operational space to conduct their religious rituals. They indicated that there were instances when their Pentecostal counterparts seemed to be getting political support to suppress the former's decisions and programmes especially if the latter suspected that the programmes could mobilise membership. All the eight Muslims revealed that there was a deliberate policy by the government to ensure that all Islamic holidays are either not recognised and celebrated, or are celebrated in private as a way of stopping Islam from recruiting more followers or becoming popular. They reported that in 2003, for instance, the Muslim community appealed to relevant government departments over Christian teachings in schools. Led by the Islamic Covenant of the Strict Observance (ICSO), an umbrella body of parents of Muslim children going to schools in Harare, the parents argued that the school 
curriculum was ultra vires section 19 of the constitution of Zimbabwe, which assured freedoms of religion and conscience. The appeal also argued that Zimbabwe's school calendar provided for only Christian holidays without considering other religions. Some of the holidays cited include;

1. First Day of Ramadan (May 27) Saturday, 1st Ramadan, 1438h

2. Lailat-ul-Qadr - First (June 15) Thursday, 20th Ramadan, 1438h

3. Eid-ul-Fitr (June 25) Sunday, 1st Shawwal, 1438h

4. Hajj Starting Day (August 30) Wednesday, 8th Dhul Hijjah, 1438h

5. Arafa Day (august 31) Thursday, 9th Dhul Hijjah, 1438h

6. Eid-ul-Adha (September 1) Friday, 10th Dhul Hijjah, 1438h

7. Day of Aashoora (September 30) Saturday, 10th Muharram, 1439h

Fifteen participants from Hinduism (8) and Islam (7) reported that in the 1990s, representatives of minority religions had petitioned government on the teaching of Bible Knowledge arguing that it amounted to turning Zimbabwe into a Christian state. However, 11 of the participants (7 Hindu and 4 Muslims) indicated that as a result of the pressure, by year 2000, the Ministry of Education, Sports and Culture had resolved to drop Bible Knowledge from the school curriculum and replacing it with Moral Education.

Another area that had sparked conflicts within the religious front as argued by Lewis was over the deprivation of public space of other religions to conduct prayers and rituals during national gatherings and at state university graduations and meetings. ${ }^{20}$ This concern was mainly raised by minority religions who accused Pentecostalism of playing bully. However, there were also voices within the Hindu participants over what they termed 'disturbing' prayer bells at specific times of the day by the Moslem community.

Thirty participants ( 8 Muslims, 8 Pentecostals, 8 Hindus and 6 ATR) indicated their strong disapproval of prostitution, suicide, abortion, and homosexuality. They all however indicated that conflict amongst religious groups in Zimbabwe was more worrying than other pressing problems like unemployment, crime, and corruption. They pointed out that the stance by respective government authorities of allowing one religion to dominate others may work in the short-term but that the stance is fraught with explosive repercussions, in the long run. 24 participants ( 8 Muslims, 8 Hindus and 8 ATR) urged the government to practise what is in the constitution with regards to religious secularism.

Seven participants (3 Muslims, 2 Hindus and 2 ATR) indicated that Pentecostalism had entrenched a belief in most institutions of uncontested dominance where all the required rituals had to follow Pentecostal practices. They cited the following conflict cases;

1. The refusal by the High Court to swear-in Munyaradzi Gwisai in 1998 as a practicing lawyer, arguing that he was dread-locked. His defence was that he followed Rastafarian religion. 
2. In 2009, two Muslims in their religious attire were systematically removed from the outside gardens of the parliament during an official opening by the Zimbabwe President.

3. In 2012, a Muslim was temporarily detained at Harare International Airport for conducting prayers within the outside restaurant area.

4. In 2014, Justice Davison Moses Foroma struggled to be allowed to be sworn-in as a judge using Koran instead of Bible.

5. Muslim students in public schools are not allowed their apparel especially the burqa.

6. Forced recital of the national pledge in schools by the relevant ministry. Apparently, the pledge is interpreted by some Zimbabweans as driving an Islamic agenda.

Two Muslim participants reported that, based on suspicions, Pentecostals were accusing Muslims of making elusive endeavours to embed Islam by way of constructing mosques, availing scholarships, giving food and relief support. On the same subject, six Hindus expressed that though there were followers in Zimbabwe, there had never been rivers in the vicinity of Harare specifically spared for Hindu rituals. As a result, according to the participants, during Hindu cremation ceremonies, ashes are not given over to sacred waters as per their religion, but are buried underground.

\section{Discussion}

The popular view that Pentecostalism preaches peace and forgiveness while, Islam prefers war as an admissible means of disseminating its word, law and culture has failed to come to the fore in this study. Rather, it has been established that if ever there were conflicts in Zimbabwe, they involved Pentecostals and no other religion. It also seems as if there is some silent policy in Zimbabwe of ensuring that only one religion dominates as a way of preventing competition, which brews conflicts. This is in view of extreme fundamentalism within Islam which is feared as violent and unending. It is unfortunate that there is a belief in Zimbabwe that Islam has strengthened various dictatorial governments that have manipulated religious emotion to ricochet civic anger away and fuel hate towards others. Religiously, people are generally attracted to whatever ideology that best protects their personal interests and claim to have some tangible deliverance. This perspective to some extent, forces the study to appreciate why majority Zimbabweans align themselves with Pentecostalism over their traditional beliefs. There is wide evidence of mass mobilisation by Pentecostals and presentation of miracles and other activities that pledge to address socio-economic challenges bedevilling Zimbabwe since around year 2000.

It is acknowledged that every single conviction that people attempt to express politically is engrained in some beliefs, religious conviction or some expectations about society and its well-being. This explains why religions; ATR, 
Pentecostalism, Muslims, or Hindus may strive for laws passed in their religious beliefs. One would think that such laws are proper for as long as they serve social interest and not just a particular religious institution. Whether these laws are prudent and judicious or worthy of enactment should be measured by their capacity to uphold the common good as defined by national principles and not merely by the fact that they are or not engrained in the religions of their promoters. Government and its relevant entities should endeavour to ensure a balanced distribution of recognition and responsibilities amongst all the existing religions if equality and democracy are to be seen and practiced.

Realizing the evident discrimination in all facets of life in Zimbabwe, there are some efforts in isolated sectors meant to review and possibly revisit the generality of the peoples' rights. A case in point especially in the education sector is enshrined in the 7 year curriculum review plan (2015-2022) by the Curriculum Development and Technical Unit (CDTU). This initiative realizes that the family is the basic and first level that provides initial orientation of any child and in particular any learner in the world. Therefore, family units are allowed to socialize their children towards realizing the value in all religious institutions of the likes of ATR, Christianity, Islam, and Hinduism amongst others. According to CDTU, Zimbabwe's education had for too long given preference to Christianity ahead of others and this had deprived learners of the right to choose the religion they wanted to follow as they grow up. According to CDTU, the new Curriculum Framework acknowledged that religion naturally has a pervasive influence in society, hence the need to open spaces for all religious orientations so learners could choose best practices from a variety of religions.

While all the participants generally see conflict among religious groups in Zimbabwe as a brash problem in comparison with other problems like crime, unemployment and corruption, the level of tolerance supported by an effective constitution create a conducive environment for sustainable peace and coexistence. It has also been observed that most Pentecostals do not see Muslims in good light just as much as the Muslims don't see Pentecostals in good light. However, Hindus believe that most Pentecostals are hostile toward them hence their withdrawal from the limelight. Hindus also view Muslims as a violent people.

\section{Conclusion}

What may be concluded in this study is that most religions expressed apprehension about fanatical religious groups, including within their own religious communities. As a result of media reports, most participants perceive widespread anti-Muslim and anti-Pentecostalism hostility in various religious communities. The study also concludes that there may have been a deliberate but silent agenda by Pentecostals to promote Christianity over other religions for two possible reasons; because the leadership subscribes to Christianity or as a way of controlling and keeping other religions under close check. Efforts by the Ministry of Education to review the curricula may go a long way in opening religious 
spaces. Similar efforts could also help from the urban settlement and housing perspectives. There is also need for strict adherence to the constitution of Zimbabwe which clearly states that Zimbabwe is a secular state. Legally and technically, no religion must enjoy more space and recognition especially in public institutions and gatherings.

\section{Notes and References}

1 Government of Zimbabwe (GoZ), Constitution of Zimbabwe, (Harare: Government of Zimbabwe, 2015).

2 Zimbabwe Demographic Survey, Zimbabwe Demographic Survey for 20102011, (Government Printers, Harare, 2012).

3 E. Chitando, Prayers \& Players: Religion and Politics in Zimbabwe, (Harare: Sapes Books, 2013).

4 O. Dodo, G. Banda and G. Dodo "African Initiated Churches in Peacebuilding: Case of the Johane Mosowe Church", Journal of Religion and Society, 16 (2014).

5 O. Dodo, Endogenous Conflict Resolution Approaches: The Zezuru Perspective, (Harare: IDA, 2015).

6 T. Barnes, The Kingfisher Book of Religions; Ceremonies and Beliefs from around the World, New York: Kingfisher, 1999; See also M. P. Osborne, One World, Many Religions: The Ways we Worship, (New York: Alfred A. Knopf, 1996).

7 O. Dodo, The History of Conflict Resolution in Zimbabwe, (Bindura: BUSE Press, (forthcoming)).

8 F. Pratto, Social dominance theory, in M.P. Zanna (ed.), Advances in Experimental Social Psychology, 31, 192-263, (New York: Academic Press, 1999).

9 F. Pratto, J. Sidanius, L.M. Stallworth, and B.F. Malle, 'Social dominance orientation: A personality variable predicting social and political attitudes'. Journal of Personality and Social Psychology, 67, 1994: 741-763. See also F. Pratto, J. Sidanius, and S. Levin, (2006) 'Social dominance theory and the dynamics of intergroup relations: Taking stock and looking forward'. European Review of Social Psychology, 17, (2006): 271-320. Also, F. Pratto, Social dominance theory, in M.P. Zanna (ed.), Advances in Experimental Social Psychology, 31, 192-263, (New York: Academic Press, 1999).

10 B. Lewis, 'The roots of Muslim rage: Why so many Muslims deeply resent the West, and why their bitterness will not easily be mollified'. The Atlantic Monthly, 266, (1990): 47-60; Pew Forum on Religion \& Public Life (PFRPL), Tolerance and Tension: Islam and Christianity in Sub-Saharan Africa, (Pew Research Center, Washington, 2010).

11 C. Sampson, "Religion and Peacebuilding" Peacemaking in W. Zartman and J. L Rasmussen (eds), International Conflict: Methods and Techniques. 
Washington DC: United States Institute of Peace Press, 1997. See also Pew Forum on Religion \& Public Life (PFRPL), Tolerance and Tension: Islam and Christianity in Sub-Saharan Africa, (Pew Research Center, Washington, 2010).

12 Pew Forum on Religion \& Public Life (PFRPL), Tolerance and Tension: Islam and Christianity in Sub-Saharan Africa, (Washington: Pew Research Center, 2010).

13 N. Bhebe, Christianity and Traditional Religions in Western Zimbabwe: 1859-1923, Britain: Longman, 1979. See also Kroc Institute for International Peace Studies (KIIPS). Women and the Contested State: Religion, Violence and Agency in South and Southeast Asia, (Notre Dame Press, 2008).

14 P.G. Devine, "Stereotypes and prejudice: Their automatic and controlled components", Journal of Personality and Social Psychology, 56, 1989: 518.

15 Church and Civil Society Forum (CCSF), A Study on the Role of the Church in Violence in Zimbabwe, Harare: National Association of NonGovernmental Organisations (NANGO), 2012.

16 Catholic Commission for Justice and Peace (CCJP) and ZLF, Breaking the silence, building true peace: a report on the disturbances in Matabeleland and the Midlands (1980 to 1988), Harare: Catholic Commission for Justice and Peace in Zimbabwe and Legal Resources Foundation, 1997.

17 C. Sampson, "Religion and Peacebuilding" Peacemaking in W. Zartman and J. L Rasmussen (eds), International Conflict: Methods and Techniques. Washington DC: United States Institute of Peace Press, 1997. See also N. Bhebe The ZAPU and ZANU Guerrilla Warfare and the Evangelical Lutheran Church in Zimbabwe. (UZ, Harare, 1999).

18 O. Dodo, The History of Conflict Resolution in Zimbabwe, (Bindura: BUSE Press, (forthcoming)).

19 P.G. Devine, "Stereotypes and prejudice: Their automatic and controlled components", Journal of Personality and Social Psychology, 56, 1989: 518.

20 B. Lewis, 'The roots of Muslim rage: Why so many Muslims deeply resent the West, and why their bitterness will not easily be mollified'. The Atlantic Monthly, 266, 1990. 